\title{
Role of Micronutrients in Improving Fruit Quality and Yield of Strawberry cv. Chandler under Microclimatic Conditions
}

\author{
Sanjeela Sabahat ${ }^{*}$, Juliya Abbasi ${ }^{2}$, Mushtaq Ahmad ${ }^{1}$, Saima Mumtaz ${ }^{1}$, Taj Naseeb Khan ${ }^{1}$, Sudheer Tariq ${ }^{1}$ \\ and Muhammad Imran ${ }^{1}$
}

\section{${ }^{1}$ Horticultural Research Institute (HRI), NARC, Islamabad, Pakistan; ${ }^{2}$ Plant Physiology Program, NARC, Islamabad, Pakistan.}

Abstract | Strawberry (Fragaria $\mathrm{x}$ ananasa) is a widely grown fruit crop known for its color, aroma and texture. The fruit is enriched with vitamin $\mathrm{C}$, manganese and antioxidants. In Pakistan, except for a few low-temperature regions, it is mainly grown as an annual fruit crop where runners are transplanted every year. Owing to its short growing period and high profitability, it is mostly produced by small scale farmers. However, the changing climate from the past few years has affected strawberry production in Pakistan. Heavy rainfall, along with hailstorms causes damage at the fruit initiation stage. Moreover, the rainfall also lead to the leaching down of the essential micronutrients in strawberry farms. In this study we have tested the foliar application of four micronutrients, iron, zinc, copper and boron, at different concentrations under tunnel conditions on strawberry cv. Chandler at Horticultural Research Institute (HRI), National Agricultural Research Centre (NARC), Islamabad. The experiment was laid out in a randomized complete block design with three blocks. Our study showed that the $0.2 \% \mathrm{ZnSO} 4$ and $0.4 \% \mathrm{FeSO} 4$ showed maximum mean values for fruit weight (18.22 g), fruit width (32.66 $\mathrm{cm})$, yield per plant $(175.84 \mathrm{~g})$, no. of fruits per plant $(10.26)$ and fruit set percentage $(87.85 \%)$. The foliar application of boron at $0.2 \%$ maximized the total soluble salts (TSS) $\left(8.3^{\circ} \mathrm{B}\right)$ and the least amount of titratable fruit acidity $(0.27 \%)$. The research findings also showed that combine application of Iron, Zinc and Boron in the given percentage can possibly improve the yield and quality of Chandler under microclimatic conditions.

Received | December 15, 2020; Accepted | December 23, 2021; Published | January 12, 2022

*Correspondence $\mid$ Sanjeela Sabahat, Horticultural Research Institute (HRI), NARC, Islamabad, Pakistan; Email: sanjeelasabahat@gmail.com Citation | Sabahat, S., J. Abbasi, S. Mumtaz, S. Tariq, M. Imran, M. Ahmad and T.N. Khan. 2021. Role of micronutrients in improving fruit quality and yield of strawberry cv. chandler under microclimatic conditions. Pakistan Journal of Agricultural Research, 34(4): 897-904.

DOI | https://dx.doi.org/10.17582/journal.pjar/2021/34.4.897.904

Keywords | Strawberry, Micronutrients, Tunnel, Foliar application

\section{Introduction}

Strawberry (Fragaria $\mathrm{x}$ ananassa Duch.) is an octaploid hybrid of the genus Fragaria (Rubiaceae family). It is a low growing perennial plant cultivated worldwide for its fruit. Botanically, its fruit is described as an aggregate accessory fruit. In 2016, strawberry production reached 9.1 million tonnes, with China accounting for 42 percent of the global output, followed by the US (16 percent) and Mexico and Egypt (5 percent each). (Trejo-Téllez and
Gómez-Merino, 2014; Global market update: strawberry, 2019).

In Pakistan, strawberry is grown as an annual crop in parts of Punjab and KPK province (Afridi et al., 2009). The crop is cultivated in November and fruit is ready to harvest in April-May. Its total area under cultivation is 387 hectares with an annual production of 795 tonnes (MNFSR, 2020). The maximum average yield lies between 5-10 tonnes per hectares. Since it is a relatively newly introduced crop, it's per acre 
production in Pakistan is not comparable to global production. Its commonly grown varieties include Chandler, Corona, Douglas, Gorella, Toro and Tuft (Rajwana et al., 2017). Chandler is high yielding, has larger fruit size, high photosynthetic activity and can easily be grown under tunnel conditions. (Kadir et al., 2006).

Apart from macronutrients, the importance of micronutrients cannot be denied in plant growth and development. These include iron, copper, zinc, boron, manganese and molybdenum. Iron plays a main role in the biosynthesis of chlorophylls and cytochromes and its deficiency can result in the bleaching of leaves. Zinc plays a vital role in pollination, fruit setting and improving fruit quality parameters such as increased sugar and decreasing acidity levels. Its deficiency can result in immature leaves (Neuweiler et al., 1996; Abedy, 2001; Abdollahi et al., 2012; Hafeez et al., 2013; Singh et al., 2015). Boron is reported to play an important role in plant cell growth and is also involved in many physiological processes such as phenol metabolism and tissue differentiation (Barker and Pilbeam, 2006). Its deficiency results in leaf tip necrosis in younger leaves and a decrease in the flower size. Unlike other micronutrients, copper is of minor importance in strawberries. In case of its deficiency, the leaves and interveinal area become light green (Trejo-Téllez and Gómez-Merino, 2014).

The uptake of these micronutrients from soil depends on the cultivar, cultural practices, and soil's physical and chemical properties. Over the past few decades, the cropping pattern in Pakistan has increased soil salinity levels and soil $\mathrm{pH}$, which has caused the depletion of these micronutrients. (Ahmad et al., 2010). Their deficiency can be overcome either by foliar or basal application. The choice of method depends upon the crop type (Arevalo-Gardini et al., 2015).

In the modern agriculture system, foliar application of micronutrients is preferred as it allows quick and uniform distribution of micronutrients through leaves and meets the plants' needs regardless of soil condition (Kerin and Berova, 2003). On the contrary, the basal application might result in leaching down of the applied micronutrients. Moreover, calcareous soils with high $\mathrm{pH}$ also hinder the availability of basally applied micronutrients, resulting in stunted growth of new shoots, chlorosis and mottled leaves (Sharma et al., 1990).
The plastic covers or tunnels are getting popular for the production of fruits and vegetables. They can facilitate crop yield by providing a controlled environment, reducing the risk of fruit damage caused by heavy rainfall, hailstorms, or fungal diseases. They also allow extended harvesting periods (Wittwer and Castilla, 1995; Jiang et al., 2003; Jett, 2007). Growing strawberries under the tunnel are reported to have increased photosynthesis rate as light penetration to lower leaves is improved and earlier flowering and fruiting is promoted. (Baeza and López, 2012).

In Pakistan, farmers lack the basic knowledge of an optimized, cost-effective procedure for the applying micronutrients on strawberries. The following study is carried out to optimize the concentration of different micronutrients through foliar application and study their effect on the growth, quality, and yield of strawberries under tunnel conditions.

\section{Material and Methods}

The experiment was performed at the experimental field of Fruit Crop Research Program, Horticulture Research Institute (HRI), National Agriculture Research Centre (NARC), Islamabad, during 20192020. The experimental site is located at $33.6844^{\circ}$ North, $73.0479^{\circ}$ East on the global scale. The runners of the strawberry cultivar "Chandler" were obtained from Swat. The seedlings of uniform size runners were transplanted in a randomized complete block design with three blocks and three replications per block by the end of November. The plant-to-plant distance was $50 \times 30 \mathrm{~cm}$. During the study, the minimum temperature ranged from $4-5{ }^{\circ} \mathrm{C}$ (during December-January), and the maximum temperature ranged from $30-35^{\circ} \mathrm{C}$ (during May-June). Beds were irrigated at the time of transplanting and later, the frequency of watering was decided based upon the soil moisture status confirmed through visual observation. The soil's physical and chemical properties are given in Table 1.

Eleven different treatments include Control (T1), individual application of $\mathrm{FeSO} 4$ (Iron), $\mathrm{CuSO} 4$ (copper) and $\mathrm{ZnSO} 4$ (Zinc) in low concentration of $0.2 \%$ (T2-T4) and in higher concentration $0.4 \%$ (T5-T7). H3BO3 (Boron) was applied at 0.1\% (T8), $0.2 \%$ (T9) and in combination with $0.4 \% \mathrm{FeSO} 4$ (0.2\% H3BO3+0.4\% FeSO4) (T10). Finally, all four micronutrients were applied @0.25\% each (T11). 
Table 1: Physical and chemical properties of the experimental land. Data was taken from the Soil Science Department, Land Resource Research Institute (LRRI), NARC, Islamabad.

$\begin{array}{llllllllll}\text { Soil Depth }(\mathbf{c m}) & \mathbf{p H} & \mathbf{E C}(\mathbf{d c} / \mathbf{m}) & \mathbf{C a C O}_{3} \% & \begin{array}{l}\text { Organic } \\ \text { matter \% }\end{array} & \mathbf{N a H C O}_{3} & \begin{array}{l}\text { Exchangeable } \\ \text { Potassium }(\mathrm{K})\end{array} & \mathbf{Z n}(\mathbf{m g}) & \mathbf{C u}(\mathbf{m g}) & \mathbf{F e}(\mathbf{m g}) \\ 0-15 & 8.1 & 0.16 & 4.0 & 2.0 & 4.9 & 48 & 0.34 & 0.46 & 6.6 \\ 30-45 & 7.9 & 0.16 & 4.0 & 1.8 & 2.5 & 38 & 0.28 & 0.50 & 4.2\end{array}$

Table 2: Analysis of variance of effect of different micronutrient treatments on vegetative, yield and quality parameters of strawberry.

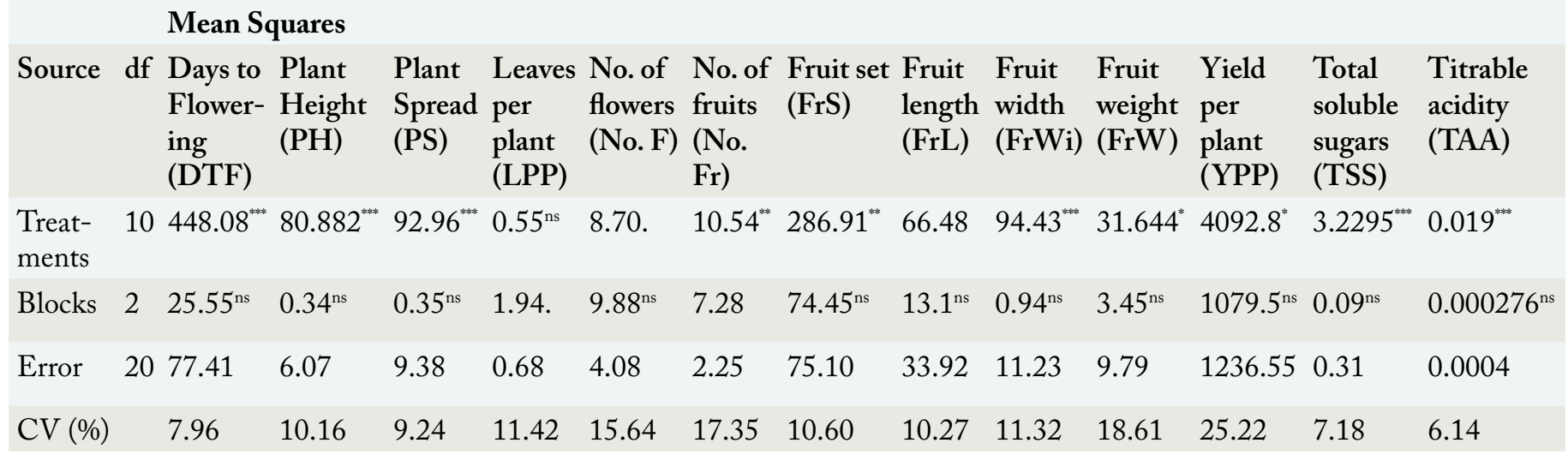

"Significant at $P<0.000$, "Significant at $P<0.001$, "Significant at $P<0.01$, ns Indicates Not significant.

The foliar application was started one month after the transplantation of runners. All plants were sprayed at vegetative (one month after transplantation), flowering (two months after transplantation) and fruiting (three months after transplantation) stage. Data on twelve different parameters were recorded at the time of plant maturity. These include quality parameters such as total soluble salts (TSS), titratable acidity (TA); yield parameters such as number of fruits, Yield per plant, fruit weight, fruit set percentage and other parameters such as days to flowering, plant height, plant spread, number of flowers, fruit length and fruit width. TSS was measured through a hand-refractometer (ATAGO, ATC-1, Tokyo, Japan) and Titratable acidity was determined through acid-based titration method as described by Ozkurt and Altunta (2018). Data were analyzed using $\mathrm{R}$ studio ( $\mathrm{R}$ Core Team, 2020). The mean performance of different treatments was analyzed through analysis of variance (ANOVA) followed by Tukey's HSD post hoc test. Correlation between different parameters was also calculated.

\section{Results and Discussion}

Table 2 showed the results of ANOVA of the effect of different micronutrient treatments on various vegetative, yield and quality parameters of strawberry Chandler. Except for the number of flowers and fruit length, there was a significant difference between all parameters against different treatment applications.

Table 3 showed the pairwise mean comparison (Tukey's HSD) effect of all treatments on the mean performance of ten traits in strawberry cv. Chandler. The foliar application of $\mathrm{H} 3 \mathrm{BO} 3$ resulted in improved fruit quality. At $0.2 \% \mathrm{H} 3 \mathrm{BO} 3$ (T9), the TSS was a maximum of $8.3^{\circ} \mathrm{Bx}$, unlike $6.7^{\circ} \mathrm{Bx}$ in the control (T1) and a minimum of $4.5^{\circ} \mathrm{Bx}$ against T7. At 0.1 $\% \mathrm{H} 3 \mathrm{BO} 3$ (T8), the TA was the lowest at $0.22 \%$ compared to the maximum value of $0.51 \%$ for $\mathrm{T} 11$. The H3BO3 was also found to have an intermediate effect on improving other parameters such as fruit weight and yield per plant. FeSO 4 treatment contributed both towards vegetative and yield parameters. A low concentration of $0.2 \%$ (T2) helped improve vegetative traits such as plant height of $29.89 \mathrm{~cm}$ and a plant spread of $35.99 \mathrm{~cm}$ against a minimum value of $14 \mathrm{~cm}$ and $21 \mathrm{~cm}$, respectively, in T6. Its high concentration of $0.4 \%$ (T5) improved yield parameters such as maximizing fruit set percentage to $87.85 \%$ (minimum $57.26 \%$ in T1) and yield per plant to175.84 $\mathrm{g}$ (minimum $69.47 \mathrm{~g}$ T6). For $\mathrm{ZnSO} 4$, compared to the fruit weight of $13.22 \mathrm{~g}$ in control (T1) and fruit width of $13.4 \mathrm{~mm}$ in $\mathrm{T} 7$, maximum fruit weight of $18.22 \mathrm{~g}$ and fruit width of $32.66 \mathrm{~mm}$ was obtained with T4 (0.2\%) treatment. Also, only T4 resulted in improved yield as the remaining treatments were not significantly different from each other. 
Table 3: Means comparison (Tukey HSD) of the different micronutrient application on various traits of strawberry cv. Chandler. Letter indicates significant difference between treatment means.

\begin{tabular}{|c|c|c|c|c|c|c|c|c|c|c|c|}
\hline Labels & Treatments & $\begin{array}{l}\text { Days to } \\
\text { flowering }\end{array}$ & $\begin{array}{l}\text { Plant } \\
\text { height }\end{array}$ & $\begin{array}{l}\text { Plant } \\
\text { Spread }\end{array}$ & $\begin{array}{l}\text { No. of } \\
\text { fruits }\end{array}$ & $\begin{array}{l}\text { Fruit set } \\
\text { percentage }\end{array}$ & $\begin{array}{l}\text { Fruit } \\
\text { width }\end{array}$ & $\begin{array}{l}\text { Fruit } \\
\text { weight }\end{array}$ & $\begin{array}{l}\text { Yield per } \\
\text { plant }\end{array}$ & $\begin{array}{l}\text { Total solu- } \\
\text { ble sugars }\end{array}$ & $\begin{array}{l}\text { Titrable } \\
\text { acidity }\end{array}$ \\
\hline $\mathrm{T} 1$ & Control & $77.66^{\mathrm{b}}$ & $22.10^{\text {bcde }}$ & $23.04^{\mathrm{bc}}$ & $6.22^{\mathrm{b}}$ & $57.26^{\mathrm{b}}$ & $25.33^{\text {abcd }}$ & $13.22^{\mathrm{ab}}$ & $79.25^{\mathrm{ab}}$ & $6.7^{\mathrm{ab}}$ & $0.29^{\mathrm{cd}}$ \\
\hline $\mathrm{T} 2$ & $\mathrm{Fe}(0.2 \%)$ & $76.66^{\mathrm{b}}$ & $29.89^{a}$ & $35.99^{a}$ & $8.53^{\mathrm{ab}}$ & $72.22^{\mathrm{ab}}$ & $32.33^{\mathrm{ab}}$ & $17.66^{\mathrm{ab}}$ & $145.39^{\mathrm{ab}}$ & $5.26^{\mathrm{bcd}}$ & $0.3^{\mathrm{cd}}$ \\
\hline T3 & $\mathrm{Cu}(0.2 \%)$ & $74.66^{\mathrm{b}}$ & $28.55^{\mathrm{ab}}$ & $34.22^{\mathrm{a}}$ & $9.26^{\mathrm{ab}}$ & $78.55^{\mathrm{ab}}$ & $28.33^{\mathrm{abc}}$ & $14.55^{\mathrm{ab}}$ & $133.61^{\mathrm{ab}}$ & $6.56^{\mathrm{bc}}$ & $0.39^{\mathrm{b}}$ \\
\hline $\mathrm{T} 4$ & $\operatorname{Zn}(0.2 \%)$ & $85.66^{\mathrm{ab}}$ & $27.44^{\mathrm{abc}}$ & $27.89^{\mathrm{abc}}$ & $8.66^{\mathrm{ab}}$ & $75.98^{\mathrm{ab}}$ & $32.66^{\mathrm{a}}$ & $18.22^{\mathrm{a}}$ & $175.84^{\mathrm{a}}$ & $5.2^{\mathrm{bcd}}$ & $0.28^{\text {cd }}$ \\
\hline $\mathrm{T} 5$ & $\mathrm{Fe}(0.4 \%)$ & $77.23^{\mathrm{b}}$ & $20.78^{\text {cdef }}$ & $35.22^{\mathrm{a}}$ & $10.26^{\mathrm{ab}}$ & $87.85^{a}$ & $32^{\mathrm{ab}}$ & $17.056^{\mathrm{ab}}$ & $156.64^{\mathrm{ab}}$ & $6.23^{\mathrm{bc}}$ & $0.3^{\text {cd }}$ \\
\hline T6 & $\mathrm{Cu}(0.4 \%)$ & $104.66^{\mathrm{a}}$ & $14^{\mathrm{f}}$ & $21^{\mathrm{c}}$ & $7.4^{\mathrm{b}}$ & $81.91^{\mathrm{ab}}$ & $18.66^{\mathrm{cd}}$ & $9.27^{\mathrm{ab}}$ & $69.476^{\mathrm{b}}$ & $6.06^{\mathrm{bcd}}$ & $0.26^{\mathrm{de}}$ \\
\hline T7 & $\operatorname{Zn}(0.4 \%)$ & $105.33^{\mathrm{a}}$ & $15.22^{\mathrm{ef}}$ & $21.44^{c}$ & $9.8^{\mathrm{ab}}$ & $81.87^{\mathrm{ab}}$ & $17.66^{\mathrm{d}}$ & $8.75^{\mathrm{b}}$ & $85.59^{\mathrm{ab}}$ & $4.5^{\mathrm{d}}$ & $0.33^{\mathrm{bc}}$ \\
\hline T8 & B (0.1\%) & $66.66^{\mathrm{b}}$ & $26.11^{\text {abcd }}$ & $27.22^{\mathrm{abc}}$ & $5.84^{\mathrm{b}}$ & $66.20^{\mathrm{ab}}$ & $30.66^{\mathrm{ab}}$ & $15.33^{\mathrm{ab}}$ & $88.18^{\mathrm{ab}}$ & $5.63^{\mathrm{bcd}}$ & $0.22^{e}$ \\
\hline T9 & $\mathrm{B}(0.2 \%)$ & $83.66^{\mathrm{ab}}$ & $23.66^{\text {abcd }}$ & $31^{\mathrm{ab}}$ & $9.13^{\mathrm{ab}}$ & $79.21^{\mathrm{ab}}$ & $25.66^{\text {abcd }}$ & $13.66^{\mathrm{ab}}$ & $122.78^{\mathrm{ab}}$ & $8.3^{\mathrm{a}}$ & $0.27^{\mathrm{de}}$ \\
\hline $\mathrm{T} 10$ & $\begin{array}{l}\mathrm{B}+\mathrm{Fe}(0.2 \%+ \\
0.4 \%)\end{array}$ & $89^{\mathrm{ab}}$ & $19.78^{\text {def }}$ & $23.89^{\mathrm{bc}}$ & $8.2^{\mathrm{ab}}$ & $90.34^{a}$ & $20.33^{\text {cd }}$ & $10.97^{\mathrm{ab}}$ & $87.57^{\mathrm{ab}}$ & $5^{\mathrm{cd}}$ & $0.39^{\mathrm{b}}$ \\
\hline T11 & $\begin{array}{l}0.25 \% \text { each of } \\
\mathrm{B}+\mathrm{Fe}+\mathrm{Cu}+\mathrm{Zn}\end{array}$ & $92^{\mathrm{ab}}$ & $20.55^{\text {cdef }}$ & $24.44^{\mathrm{bc}}$ & $12.53^{\mathrm{a}}$ & $86.26^{a}$ & $22.66^{\mathrm{bcd}}$ & $12^{\mathrm{ab}}$ & $150.66^{\mathrm{ab}}$ & $5.66^{\text {bcd }}$ & $0.51^{\mathrm{a}}$ \\
\hline
\end{tabular}

However, a high concentration (0.4\%) of $\mathrm{ZnSO} 4$ (T7) resulted in the decline of both vegetative and fruit quality traits such as a minimum plant spread of $21.44 \mathrm{~cm}$, fruit weight of $8.75 \mathrm{~g}$, TSS of $4.5^{\circ} \mathrm{Bx}$, fruit width of $17.66 \mathrm{~mm}$ and longest days to flowering of 105 days. Application of $\mathrm{CuSO} 4$ at low concentration (T3) helped improve plant spread to $34.22 \mathrm{~cm}$. However, its higher concentrations (T6) resulted in a decline of vegetative traits such as plant height (14 $\mathrm{cm})$, plant spread $(21 \mathrm{~cm})$ and also increased days to flowering (104 days). The treatments that involved a combination of micronutrients only improved a few of the traits under study. For example, $\mathrm{H} 3 \mathrm{BO} 3$ and FeSO 4 treatment (T10) only improved the fruit set percentage (90.34\%). The application of all micronutrients (T11) maximized both the number of fruits ( 12) and fruit set percentage (86.26\%). However, both T10 and T11 also resulted in an increased TA of $0.39 \%$ and $0.51 \%$, respectively.

The results of the correlation between different growth, quality and yield parameters are indicated in Table 4. The maximum correlation observed for these parameters was 0.99 between fruit width and fruit weight. In contrast, a minimum positive significant correlation of 0.64 was observed for the number of fruits and yield per plant. Fruit width, fruit weight and yield per plant were strongly correlated traits.

Days to flowering showed negative correlation with plant height, plant spread, fruit width and fruit weight. Plant height showed significant positive correlation with plant spread, fruit width and fruit weight. Plant spread showed positive significant correlation with fruit width, fruit weight and yield per plant. The number of fruits were positively correlated with fruit set percentage yield per plant and titrable acidity. Fruit width showed a significant positive correlation with fruit weight and yield per plant, while fruit weight was positively correlated with yield per plant.

The mean performance of each treatment application over control is shown in Figure 1. Maximum yield per plant was observed for 0.2 percent of Zinc followed by Iron ( 0.4 percent). With increased yield per plant in the following treatments, fruit weight and fruit width were also increased. In contrast, fruit weight and fruit width were decreased in combined treatments in T10 and T11. Although 0.2\% H3BO3 application maximizes TSS, there is only a 30 percent improvement over the control. The study showed that the micronutrients primarily improved the yield parameters while no effect was found on quality parameters of strawberry fruit except for treatment T8 (0.1 percent boron), where maximum decreased value of titrable acidity was observed.

Major elements such as nitrogen, potassium, and phosphorous play an essential role in the growth development and production of strawberries. However, the importance of the secondary elements such as iron, boron, zinc, copper, etc., cannot be denied as they served as a catalyst to maintain the growth and yield. 


\begin{tabular}{|c|c|c|c|c|c|c|c|c|c|c|}
\hline & DTF & PH & PS & No. Fr & FrS & FrWi & FrW & YPP & TSS & TA \\
\hline DTF & & $-0.81^{* *}$ & $-0.67^{* \prime}$ & $0.33^{\text {ns }}$ & $0.50^{\mathrm{ns}}$ & $-0.82^{* *}$ & $-0.76^{* *}$ & $-0.33^{\mathrm{ns}}$ & $-0.31^{\mathrm{ns}}$ & $0.24^{\mathrm{ns}}$ \\
\hline $\mathrm{PH}$ & & & $0.73^{* \prime}$ & $-0.13^{\mathrm{ns}}$ & $-0.41^{\mathrm{ns}}$ & $0.84^{* *}$ & $0.84^{* *}$ & $0.51^{\mathrm{ns}}$ & $0.16^{\mathrm{ns}}$ & $-0.10^{\mathrm{ns}}$ \\
\hline PS & & & & $0.19^{\text {ns }}$ & $0.02^{\mathrm{ns}}$ & $0.79^{* *}$ & $0.79^{* * *}$ & $0.74^{* * *}$ & $0.30^{\mathrm{ns}}$ & $-0.09^{\mathrm{ns}}$ \\
\hline No. Fr & & & & & $0.69^{* *}$ & $-0.11^{\mathrm{ns}}$ & $-0.06^{\mathrm{ns}}$ & $0.64^{* *}$ & $-0.07^{\mathrm{ns}}$ & $0.75^{* *}$ \\
\hline $\mathrm{FrS}$ & & & & & & $-0.35^{\mathrm{ns}}$ & $-0.29^{\mathrm{ns}}$ & $0.30^{\mathrm{ns}}$ & $-0.19^{\mathrm{ns}}$ & $0.51^{\mathrm{ns}}$ \\
\hline FrWi & & & & & & & $0.99^{* *}$ & $0.67^{* *}$ & $0.15^{\mathrm{ns}}$ & $-0.32^{\mathrm{ns}}$ \\
\hline FrW & & & & & & & & $0.72^{+*}$ & $0.12^{\mathrm{ns}}$ & $-0.27^{\mathrm{ns}}$ \\
\hline YPP & & & & & & & & & $0.08^{\mathrm{ns}}$ & $0.28^{\mathrm{ns}}$ \\
\hline TSS & & & & & & & & & & $-0.20^{\mathrm{ns}}$ \\
\hline
\end{tabular}

TA

\section{Traits performance over Control (T1)}

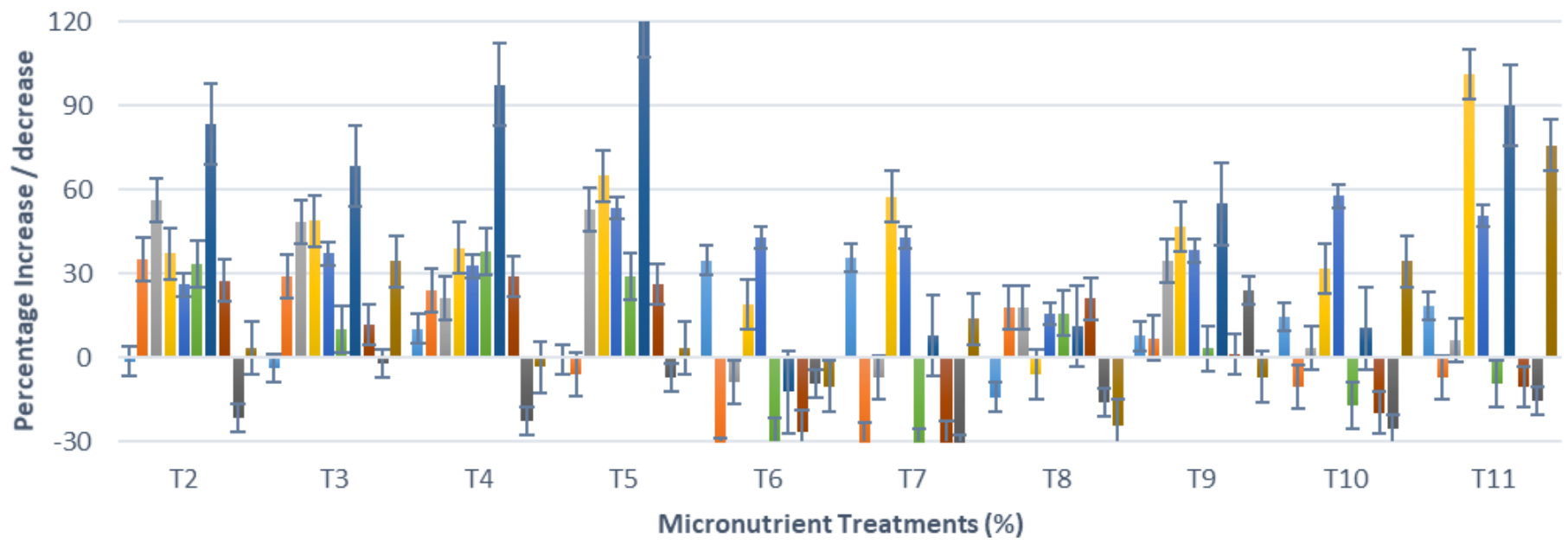

\begin{tabular}{|c|c|c|c|c|}
\hline 口 Days to flowering & 口 Plant height & E Plant Spread & No of fruits & a Fruit set percentage \\
\hline Fruit weight & - Yield per plant & a Fruit width & - Total solubl & Titrable acidity \\
\hline
\end{tabular}

Figure 1: Performance of strawberry traits over control (T1) treatment. X-axis represent micronutrient treatment (\%). Y-axis represents improvement or decline in the performance of a trait with respect to control (T1) in response to the applied treatments (T2-211).

Their deficiency may result stunted growth in plants (Casteel, 2004; Ahmad et al., 2010). Foliar application of these micronutrients assures equal distribution to the plants. And the use of plastic tunnels aid in maximizing their uptake and in the early maturity of the crop (Smolen 2012; Singh et al., 2012).

The role of micronutrients in improving the vegetative growth, fruit quality and yield of strawberry has been reported by Abdollahi et al. (2012), Domoto (2011) and Farid et al. (2020). Our findings that application of $\mathrm{FeSO} 4$ in two different concentrations, $0.2 \%$ and $0.4 \%$, improves vegetative parameters and yield respectively are inconsistent with Bakshi et al. (2013) and Ekka et al. (2018). They showed that $0.4 \%$ and $0.6 \% \mathrm{FeSO} 4$ improve the growth, quality, and yield of strawberries. However, unlike Bakshi et al. (2013) who showed $0.6 \% \mathrm{ZnSO} 4$ improved fruit quality, our findings showed that only $0.2 \% \mathrm{ZnSO} 4$ improves fruit parameters and a high concentration of $0.4 \%$ decreases growth fruit quality. These results are consistent with Shafeek et al. (2014) findings that the application of micronutrients in higher concentrations resulted in reduced plant vigor and fruit quality. Our results that both zinc and iron play a significant role is also supported by Singh et al. (2015), who showed that both $\mathrm{FeSO} 4$ and $\mathrm{ZnSO} 4$ improve vegetative and fruiting parameters. Since iron is a vital component of plant's chlorophyll preparation machinery, its foliar application can result in an increased photosynthesis activity, which can ultimately contribute towards plant yield (Gajc-Wolska et al., 2014). Meanwhile, the role of zinc in plant sustenance can be explained by the fact that it acts as a cofactor for different en- 
zymes and proteins (Sarwar et al., 2012).

Similarly, our findings of the role of boron in improving the fruit quality by reducing titrable acidity and maximizing TSS are consistent with Wojcika (1999), (2005) and Nagy et al. (2008). The role of boron in sugar translocation could help improve fruit quality parameters (Gauch and Dugger 1953; Sathya et al., 2010). Moreover, the deficiency of boron aggravate the quality of fruit by increasing titrable acidity and its application improves the quality of fruit (Haider et al., 2019). The combined effect of these three micronutrients (Iron, Zinc \& Boron) resulted in improvement of yield and quality of fruit as discussed by Bhoyar and Ramdevputra (2016). Although copper acts as a cofactor for different enzymes and its role in photosynthesis and respiration are well established, our study showed no significant role of copper in improving the growth and yield parameters of strawberries.

\section{Conclusion and Recommendations}

Based upon our findings, we suggest that the foliar application of $\mathrm{ZnSO} 4$ at $0.2 \%$ along with FeSO 4 $0.4 \%$ can be recommended for improved yield of strawberry under tunnel condition. Similarly, the application of $0.2 \%$ boron can affect the quality of fruit. For future studies, the combined effect of these concentrations on strawberry cv. Chandler production is suggested.

\section{Novelty Statement}

This is an original study performed at Horticultural research institute, NARC, Islamabad.

This manuscript was not send to any other journal for publication

\section{Author's Contribution}

Sanjeela Sabahat: Conceived and designed the experiment, performed the experimental work, wrote the first draft of the paper.

Juliya Abbasi: Performed statistical analysis, wrote the first draft of the paper.

Mushtaq Ahmad: Gave technical guidance.

Saima Mumtaz: Helped in data collection.

Taj Naseeb Khan: Procurement of strawberry germplasm, provided field space for conduction of experiment.

Sudheer Tariq: Conceived and designed the experi- ment.

Muhammad Imran: Procurement and identification of germplasm.

\section{Conflict of interest}

The authors have declared no conflict of interest.

\section{References}

Abdollahi, M., S. Eshghi, E. Tafazol and N. Moosavi. 2012. Effect of paclobutrazol, boric acid and zinc sulfate on vegetative and reproductive growth of strawberry (Fragaria $\times$ Ananassa Duch.) cv. Selva. J. Agric. Sci. Technol., 14: 357-363.

Abedy A. 2001. Effects of zinc sulphate and citric acid spray on fruit characteristics of tomato cultivar 'Urbana'. Msc. Thesis, Shiraz University, 2001.

Afridi, G.S., M. Ishaq and S. Ahmed. 2009. Cost and revenue analysis of Strawberry production in the SubTropical areas of NWFP, Pakistan. Pak. J. Life. Soc. Sci., 7(1): 59-65.

Ahmad, I., Khan, M.A., Qasim, M., Ahmad, R. and Randhawa, M.A. 2010. Growth, Yield and Quality of Rosa hybrida L. as Influenced by Various Micronutrients. Pak. J. Agric. Sci., 47: 5-12.

Arévalo-Gardini, E., Canto, M., Alegre, J., Loli, O., Julca, A. and Baligar, V. 2015. Changes in Soil Physical and Chemical Properties in Long term Improved Natural and Traditional Agroforestry Management Systems of Cacao Genotypes in Peruvian Amazon. PloS one, 10(7):L e0132147. https://doi.org/10.1371/journal.pone.0132147

Baeza, E. and J.C. López. 2012. Light transmission through greenhouse covers. Proc. 7th IS Light Hort. Sys. Acta Hort., 956:425-440. https:// doi.org/10.17660/ActaHortic.2012.956.50

Bakshi, P., A. Jasrotia, V.K. Wali, A. Sharma and M. Akshi. 2013. Influence of pre-harvest application of calcium and micro-nutrients on growth, yield, quality and shelf-life of strawberry cv "Chandler". Ind. J. Agric. Sci., 83:831-835.

Barker, A.V. and D.J. Pilbeam. 2006. Handbook of Plant Nutrition.CRC Press,Boca Raton,Florida, 3-13. https://doi.org/10.1201/9781420014877. sec1

Bhoyar, M.G. and Ramdevputra, M.V. 2016. Effect of foliar spray of zinc, iron and boron on the growth, yield and sensory characters of 
guava (Psidium guajava L.) Cv. Sardar L-49. J. Appl. Nat. Sci., 8(2): 701-704. https://doi. org/10.31018/jans.v8i2.860

Casteel, S. 2004. Strawberry fertility and nutrient management. NCDA\&CS Agronomic Division.

Domoto, P. 2011. Recognizing and correcting nutrient deficiencies in strawberries. Iowa State University-Extension.

Ekka, R.A., A. Kerketta, S. Lakra and S. Saravanan. 2018. Effect of $\mathrm{Zn}, \mathrm{B}, \mathrm{Cu}$ and $\mathrm{Fe}$ on vegetative growth, yield and quality of strawberry (Fragaria $\mathrm{x}$ ananassa Duch.) cv. Chandler. Int. J. Curr. Microbiol. App. Sci., 7: 2886-2890.

Farid, M.Z., Qureshi, K.M., Shah, S.H., Qureshi, A.A., Umair, M. and Shafiq, H. 2020. Foliar application of micronutrients improves growth, productivity and fruit quality of strawberry (fragaria ananassa duch). J. Anim. Plant Sci., 30(4): 905-912. https://doi.org/10.36899/ JAPS.2020.4.0106

Gajc-Wolska, J., Mazur, K., Niedzińska, M., Kowalczyk, K. and Żołnierczyk, P. 2014. The influence of foliar fertilizers on the quality and yield of sweet pepper (Capsicum annuum L.). Folia Horticulturae, 30(2): 183-190. https://doi.org/10.2478/fhort-2018-0008

Gauch, H.G. and Dugger, W.M. 1953. The role of boron in the translocation of sucrose. Am. Soc. Plant Biol., 28:457- 467. https://doi. org/10.1104/pp.28.3.457

Global Market Update: Strawberry.2019. Retrieved from https://www.tridge.com/market-reports/ strawberry-market-report

Hafeez, B., Khanif,Y.M. and Saleem, M. 2013. Role of zinc in plant nutrition-a review. J. Exp. Agric. Int., pp.374-391. https://doi.org/10.9734/ AJEA/2013/2746

Haider, Z., Ahmad, N., Danish, S., Iqbal, J., Ali, M.A. and Chaudhry, U.K. 2019. Effect of foliar application of boric acid on fruit quality and yield traits of mango. Adv. Hortic. Sci., 33(4): 457-465.

Jett, L.W. 2007. Growing strawberries in high tunnels in Missouri. Retrieved from http:// www.hightunnels.org/PDF/Growing_ Strawberries_in_High_Tunnels.pdf

Jiang, W.J., D.Y. Qu, D. Mu and L.R. Wang. 2003. Protected cultivation of horticultural crops in China. Hortic. Rev., 30: 115-162. https://doi. org/10.1002/9780470650837.ch4
Kadir, S., Carey, E. and Ennahli, S. 2006. Influence of high tunnel and field conditions on strawberry growth and development. HortScience, 41(2): 329-335.

https://doi.org/10.21273/ HORTSCI.41.2.329

Kerin, V. and Berova, M. 2003. Foliar fertilization in plants. Videnov \& Son, Sofia. (in Bulgarian). MNSFR. 2020. Fruit Vegetables and Condiments Statistics of Pakistan 2018-19.

Nagy, P.T., Thurzó, T., Szabó, Z. and Nyéki, J. 2008. Impact of boron foliar fertilization on annual fluctuation of B in sweet cherry leaves and fruit quality. Int. J. Hortic. Sci., 14(3): 27-30. https:// doi.org/10.31421/IJHS/14/3/798

Neuweiler,R.I.,Heuer,W.and Baumaun,D.T.1996. New ways in fertilization and soil management of strawberries. Obst-und-weinbau, 132(19): 439-499.

Ozkurt, H. and Altuntas, O. 2018. Quality Parameter Levels of Strawberry Fruit in Response to Different Sound Waves at 1000 $\mathrm{Hz}$ with Different dB Values (95, 100, 105 dB). Agronomy, 8(127):1-13. https://doi. org/10.3390/agronomy8070127

R Core Team.2020. R: A language and environment for statistical computing. R Foundation for Statistical Computing, Vienna, Austria. URL https://www.R-project.org/.

Rajwana, I.A., K. Razzaq, S.B. Hussain, M. Amin, A.S. Khan and A.U. Malik. 2017. Strawberry cultivation in southern Punjab Pakistan. Acta Horticulturae (ISHS), 1156: 909-914. https:// doi.org/10.17660/ActaHortic.2017.1156.134

Sarwar, M., Jilani, G., Rafique, E., Akhtar, M.E. and Chaudhry, A.N. 2012. Impact of integrated nutrient management on yield and nutrient uptake by maize under rainfed conditions. Pak. J. Nutr., 11(3): 27-33. https://doi.org/10.3923/ pjn.2012.27.33

Sathya, S., Mani, S., Mahedran, P.P. and Arulmozhiselvan, K. 2010. Effect of application of boron on growth, quality and fruit yield of PKM 1 tomato. Indian J. Agric. Res., 44: 274280.

Shafeek, M.R., Helmy, A., Beheiry, G., Fatma, A.R. and Nadia M.O. 2014. Foliar application of some plant nutritive compounds on growth, yield and fruit quality of hot pepper plants (Capsicum annum, L.) grown under plastic house conditions. Curr. Sci. Int., 3(1): 1-6.

Sharma, T.R., Nair, P.K. and Nema, M.K. 1990. 
Effect of foliar spray of urea, KNO3 and NAA on fruiting behavior of mango cv. Langra. Orissa J. Hort., 18: $42-47$.

Singh, A., Syndor, A., Deka, B.C., Singh, R.K. and Patel, R.K. 2012. The effect of microclimate inside low tunnels on off-season production of strawberry (Fragariax ananassa Duch.). Sci. Hortic., 144: 36-41. https://doi.org/10.1016/j. scienta.2012.06.025

Singh, M., Jamwal, M., Sharma, N., Kumar, R. and Wali, V.K. 2015. Response of iron and zinc on vegetative and reproductive growth of strawberry (Fragariax Ananassa Duch.) cv. Chandler. Bangladesh J. Bot., 44(2): 337-340. https://doi.org/10.3329/bjb.v44i2.38527

Smoleń, S. 2012. Foliar nutrition: current state of knowledge and opportunities. Adv. Citrus Nutr., pp. 41-58. Springer, Dordrecht. https:// doi.org/10.1007/978-94-007-4171-3_4
Trejo-Téllez, L.I. and Gómez-Merino, F.C. 2014. Nutrient management in strawberry: effects on yield, quality and plant health. Strawberries: Cultivation, antioxidant properties and health benefits, 1st edition. Nova Science Publishers, Inc, pp.239-267.

Wittwer, S.H. and Castilla, N. 1995. Protected cultivation of horticultural crops worldwide. Hort. Techno., 5:6-23. https://doi. org/10.21273/HORTTECH.5.1.6

Wojcik, P. 1999. Effect of boron fertilization of Dabrowicka prune trees on growth, yield and fruit quality. J. Plant Nutr., 22(10):1651-1664. https://doi.org/10.1080/01904169909365743

Wojcik P. 2005. Response of primo cane- fruiting Polana red raspberry to boron fertilization. J. Plant Nutr., 28: 1821-1832. https://doi. org/10.1080/01904160500251191 